\title{
Critical analysis of risk assessment methods applied to construction works
}

\section{Análisis crítico de los métodos de evaluación de riesgos aplicados a obras de construcción}

\author{
Antonio José Carpio de los Pinos (Main Author)
}

Escuela Técnica Superior de Edificación, Universidad Politécnica de Madrid

Av. Juan de Herrera, 6, 28040 Madrid (Spain)

aj.carpio@alumnos.upm.es

María de las Nieves González García (Correspondant Author)

Departamento Construcciones Arquitectónicas, Universidad Politécnica de Madrid

Escuela Técnica Superior de Edificación. Avda. Juan de Herrera, 6. 28040 Madrid (Spain)

Phone: 0034913367569

mariadelasnieves.gonzalez@upm.es

\author{
Manuscript Code: 705 \\ Date of Acceptance/Reception: 03.04.17/05.11.2015 \\ DOI: $10.7764 /$ RDLC.16.1.104
}

\begin{abstract}
This paper studies the possibility of using the following occupational risk assessment methods for construction works: INSHT, ANACT, THREP, SHERPA, RNUR, EVENT TREE, LEST, FINE, ERGONOMIC ANALYSIS and PSYCHOSOCIAL FACTORS. Of these methods, INSHT, ANACT, RNUR and FINE have been selected with the objective of applying them to real building works, in order to determine the discrepancies in the results obtained compared to the risks analyzed. The results make it possible to ascertain the types of risk which each method most reliably detects, there being methods which are not able to detect extreme or very low risks. It is concluded that if a single risk assessment method is used, the results do not entirely reflect reality, as such it is necessary to establish a new risk assessment methodology for construction works.
\end{abstract}

Key words: Prevention, safety at work, methodology, risk assessment, construction.

Resumen

En este trabajo se ha estudiado la posibilidad de emplear para obras de construcción los siguientes métodos de evaluación de riesgos laborales: INSHT ANACT, THREP, SHERPA, RNUR, ÁRBOL DE SUCESOS, LEST, FINE, ANÁLISIS ERGONÓMICO Y FACTORES PSICOSOCIALES. De estos métodos se han seleccionado: INSHT, ANACT, RNUR y FINE con el objetivo de aplicarlos en obras reales para comprobar las discrepancias en los resultados obtenidos frente a los mismos riesgos analizados. Los resultados permiten comprobar los tipos de riesgo que cada método detecta con más fiabilidad, existiendo métodos que no son capaces de detectar riesgos extremos o muy bajos. Se concluye que si se emplea un único método de evaluación de riesgos los resultados no reflejan en su totalidad la realidad, por lo que es necesario establecer una nueva metodología de evaluación de riesgos en obras de construcción

Palabras clave: Prevención, seguridad en el trabajo, metodología, evaluación de riesgos, construcción.

Introduction

Accidents at work constitute a major problem both in the economic and social sphere and represent a permanent economic loss for companies, administrations, workers and society in general (Suárez, Rubio \& López, 2014; Haslam et al., 2005; Silva et al., 2013). Among the professional sectors, the construction industry has always had a high rate of accidents at work (Camino, Ritzel, Fontaneda \& González, 2008; Chi, Chang \& Ting, 2005; Aneziris, Topali \& Papazoglou, 2012; National Safety Council, 2011; Segarra, Villena, González, Romero \& Rodríguez, 2017). Although statistics have gradually improved over the past years (European Commission, 2009; Haslam et al., 2005; López, Rubio \& Gibb, 2012; Sesé et al., 2002; Ministerio de Empleo y Seguridad Social, 2016), the construction sector has still a disappointing rate of incidence (Chen \& Fosbroke, 1998), with huge direct and indirect costs (Waehrer, Dong, Miller, Haile \& Men, 2007; Bobick, 2004). In Europe, as in other parts of the world, the reduction of work accidents is an immediate social priority and, as a result, accident prevention and risk management is a crucial issue within the construction industry (Martínez, Rubio \& Gibb, 2010).

The high accident rate in the construction sector is due to a series of circumstances that do not occur in other sectors. These include: temporality, high outsourcing (Hermanus, 2007), low educational level of the workers, lack of training, lack of prevention culture and communication problems (Fung, Tam, Lo \& Lu, 2010), complexity and ongoing natural changes within the work environment (Ringen, Englund, Welch, Weeks \& Seegal, 1995), the fact that every construction project is of a unique nature (Tam, Zeng \& Deng, 2004) and many times, the high number of immigrant workers who are unfamiliar with the construction, materials and methods, and often do not even speak the local language (Martínez 
et al., 2010). The "special" circumstances of this working environment require a detailed analysis of the various risks to which construction workers are exposed (Rozenfeld, Sacks, Rosenfeld \& Baum, 2010). A suitable technique for this analysis can be risk assessment, which will provide useful information that could lead to a reduction in accidents at work (Dong, Vaughan, Sullivan \& Fletcher, 1995; Hatipkarasulu, 2010).

Safety and health at work is therefore a major concern in many countries. The traditional way of improving it has been through legislation, regulation, standards and guidelines for safety, or at the same time, compilation of best practices, statistics of accidents, investigations and inspections, analysis of personal behavior and safety management systems (Aneziris et al., 2012). In order to fight working accidents, the legislation indicates that risk prevention must be integrated in all phases of the business performance (BOE, 1995). To do this, a prevention plan of working risks must be implemented using a risk assessment tool, so that from this, preventive planning within the company can be fulfilled and be prepared to fight against the occurrence of work accidents.

This paper discusses different methodologies of risk assessment applied to building construction. To this end, four methods of risk evaluation have been selected based on the criterion of better suitability to the construction sector characteristics. These four methods have been applied on three building constructions of different characteristics.

\section{Risk assessment}

The entire process of construction of a building should be considered in order to assess risks in the construction sector: from the very conception of the project until the final phase of handing over and the subsequent maintenance. Building construction is a dynamic and complex activity (Bobick, 2004) where a succession of work phases takes place; with continuous trade changes, different types of tasks, exposure to adverse weather conditions, materials, machinery, use of auxiliary means, height of work, high proportions of non-skilled and temporary workers, etc. (Rozenfeld et al., 2010). In addition, the coordination of different interdependent contractors, subcontractors, and the combination of different operations that otherwise may lead to an increased injury risk (Pinto, Nunes \& Ribeiro, 2011) is required. Throughout the construction process safety on the work site plays a fundamental role, since risks are varied and change according to the evolution of the work being performed. Analysis and management of risks in construction depend mainly on intuition, judgment and experience. Therefore, a more specific methodology for risk assessment in construction and adapted to those circumstances becomes essential.

A matter of special interest lies in the consideration of prevention right from the project stage (Lorent, 1987; Haslam et al., 2005; Behm, 2005; Gangolells, Casals, Forcada, Roca \& Fuertes, 2010). Previous studies highlight the relationship between design and safety, and that the consideration of safety already from the design phase is an effective technique to reduce or eliminate risk situations. However, the reduction and elimination of risks is a multidisciplinary task requiring the participation of all the stakeholders involved in the work (Gambatase, Behm \& Rajendran, 2008).

Risk assessment is often described as a process consisting of three distinct phases: identification of risks, risk estimation and risk assessment. These phases are considered the starting point for the development of risk assessment methods. Tixier (Tixier, Dusserre, Salvi \& Gaston, 2002) indicates that generally three main phases are identified when making a study of evaluation of occupational risks:

Phase 1 - Identification of the potential dangers.

Phase 2 - Risk assessment in order to quantify the risk. It may be done with a deterministic, or a probabilistic approach, or with a combination of both. Nuclear methods are based on the frequency of the occurrence of hazardous situations and accidents.

Phase 3 - Organization into a hierarchy.

Different risk assessment methods can be classified from simple ones, which comprise a single step, to more complex methods, which include the three previous steps. The output data can be qualitative, such as recommendations, or quantitative, as in an index form of the level of risk (Pinto et al., 2011).

Risk assessment enables the identification of risk factors, their assessment and prioritization (Conte, Rubio, García \& Cano, 2011), from which mechanisms to control risks are established. The purpose of risk assessment is to determine if the level of risk from work activities is acceptable or otherwise, measures must be taken to control and reduce risk (Gadd, Keeley \& Balmforth, 2004). To this end, the probability of damage occurring to a worker on the basis of risk exposure is analyzed. In this way, Jannadi and Almishari (2003) presented a study on risk assessment of major construction activities, defining risk as a measure of dangers probability, severity and exposure of an activity. This is also the same approach taken by Barandan and Usmen in their study of 16 construction trades (Barandan \& Usmen, 2006). 
This study was based on the definition of risk as the product of probability (frequency) and severity. They noted that the simultaneous consideration of the frequency and severity shows broader results than analyzing risk based only on frequency or on severity. According to Williams (1993), risk depends on two factors; the probability of occurrence and the impact that is quantified as the consequences on workers and their environment.

Using a mathematical description, the above can be described as $R=P \cdot I$, where $R$ is the level of risk within the interval $[0,1], P$ is the probability of it occurring within $[0,1]$, and I is the risk impact, within $[0,1]$. The analysis of the equation above implies that the risk level is close to 0 when its impact is very small or it has a very low probability of occurring. When a risk has a high occurrence probability and a impact, the risk level is close to 1 .

Faber \& Stewart (2003) defines the same concept in technical risk as the expected consequences associated with a given activity. Taking into account an activity with a single event, the risk $R$, is the probability of this event occurring $P$, multiplied by the consequences $C$. That is: $R=P \cdot C$.

There are two main ways to obtain the risk probability of occurrence: a subjective analysis and an objective analysis. The subjective analysis is based on the direct estimation of the risk probability of occurrence and requires a high level of expertise. Objective analysis needs historical data to carry out the evaluation, in some cases it is not viable for all risks due to lack of information (Zhi, 1995).

Quantification of the risk impact is a difficult task because a same accident can produce multiple consequences and there may be different opinions on assessing the severity of the same damage (Pinto, Ribeiro \& Nunes, 2012).

Assessment methods of the analysed risks

\begin{tabular}{|c|c|c|c|c|c|}
\hline Method & $\begin{array}{c}\text { Analyzed } \\
\text { risks }\end{array}$ & $\begin{array}{l}\text { Applicability } \\
\text { range }\end{array}$ & $\begin{array}{c}\text { Parameters of } \\
\text { use }\end{array}$ & $\begin{array}{c}\text { Type of } \\
\text { evaluation }\end{array}$ & $\begin{array}{c}\text { Applicable to } \\
\text { construction works }\end{array}$ \\
\hline INSHT & Global & General & Qualitative & Tolerance & Yes \\
\hline ANACT & Global & Large industry & Qualitative & Important & Yes \\
\hline THERP & Partial & Industry & $\begin{array}{c}\text { Qualitative } \\
\text { Quantitative }\end{array}$ & Probability & No \\
\hline SHERPA & Partial & Industry & $\begin{array}{l}\text { Qualitative } \\
\text { Quantitative }\end{array}$ & Probability & No \\
\hline RNUR & Global & $\begin{array}{l}\text { Production } \\
\text { chains }\end{array}$ & Qualitative & Satisfaction & Yes \\
\hline EVENT TREE & Partial & Production chains & $\begin{array}{l}\text { Qualitative } \\
\text { Quantitative }\end{array}$ & $\begin{array}{c}\text { Probability of the } \\
\text { incident }\end{array}$ & No \\
\hline LEST & Global & Production chains & $\begin{array}{l}\text { Qualitative } \\
\text { Quantitative }\end{array}$ & Description & No \\
\hline FINE & Global & General & Quantitative & Risk significance & Yes \\
\hline ERGONOMIC & Partial & Industry & Qualitative & Description & No \\
\hline PSYCHOSOCIAL & Partial & General & Qualitative & Risk profile & No \\
\hline
\end{tabular}

Ten methods of risk assessment have been analyzed, comparing them regarding the following criteria: whether the method analyzes global or partial risks, the type of company, the use of qualitative or quantitative parameters, the type of evaluation carried out and, finally, whether the method has an adaptation to be used in building works. Table 1 shows the selected evaluation methods, the comparison analysis and their suitability for the construction works. The analyzed methods are the following:

- INSHT. Method proposed by the National Institute of Safety and Hygiene at work (Gómez-Cano, et al., 1996). It is based on a risk matrix allowing the estimation of risks, in terms of frequency and severity (López-Arquillos \& RubioRomero, 2015).

- ANACT. Method of the Agence Nationale pour l' amélioration des Conditions de Travail (Nogareda, 1988).

- THERP. The Method for the Prediction of the Human Error is the most used technique to estimate the impact of human error (Lewis \& Stine, 1989). It allows to predict the probability of human error in carrying out the tasks.

- SHERPA (Embrey, 1986). Method based on the functional analysis of the human behavior. 
- RNUR. Method of job profiles. It objectively rates all the variables of the place of work to improve personal safety and that of the environment, decreasing the physical and mental burden, lowering the repetitive or chain annoyances and increasing posts of high work content (Chavarría, 1986).

- EVENT TREE. Method that allows to study, with a graphic diagram, sequential processes of hypothetical accidents from unwanted initial events, or probable subsequent developments and verifying whether existing or planned preventive measures are enough to limit or minimize the negative effects (Bestratén, 1994). The probability of occurrence of a specific path can be obtained by multiplying the probabilities of all subsequent events in one way (Hon, Lee, Shin, Nam \& Kong, 2009). It is a qualitative and quantitative risk analysis technique (Ferdous, Khan, Sadiq, Amyotte \& Veitch, 2009).

- LEST (Guelaud et al., 1975; Pérez, 1986). It serves to evaluate the ergonomic psychosocial factors affecting the physical environment negatively, the burden of physical work, the psychosocial aspects, and the hours of workers job (Callejon-Ferre, Pérez-Alonso, Carreño-Ortega \& Velázquez-Martí, 2011).

- FINE. This technique (Fine \& Kinney, 1971) uses a formula to calculate the quantified risk due to the danger. The risk is calculated taking into account the possible consequences of an accident, the exposure factor and the probability factor. (Marhavilas, Koulouriotis \& Gemeni, 2011).

- ERGONOMIC (Nogareda, 1995; Ahonen, Launis \& Kuorinka, 1989). Method comprising a systematic and thorough description of the task or job, using observations and interviews to obtain the necessary information.

- PSYCHOSOCIAL (Pérez \& Nogareda, 2012). It is a method edited by the National Institute of safety and hygiene in Spanish work (INSHT), including a computer application for prevention, called F-Psycho. Method of evaluation of the psychosocial factors, it allows for the identification and assessment of a company or of partial areas of psychosocial risk.

Based on the application concepts in building works, the methods of risk assessment that better adapt to the complexity of the building construction development and to the objective of the work are the INSHT method of the National Institute of safety and hygiene at work (Gómez-Cano, et al., 1996), the ANACT method, the Régie Nationale Des Usines Renault RNUR method, and the method of FINE by William T. Fine (Rubio, 2005).

Obviously, there are many and different assessment methodologies of work risk. But, particularly, for construction works no satisfactory results have been found in the research performed for this work. Therefore, the methods selected, both in the preliminary study, as well as in the inclusion of an analysis of the methodologies to be applied in building works, have been from a practical point of view in relation to the objective of the research.

\section{Experimental procedure performed}

Experimental work has been performed studying the safety conditions during the execution of three construction works taking place in Spain. In the selection of the works to be analyzed, building works with very different characteristics have been searched. In addition, public and privately developed works, new building constructions, as well as rehabilitation works located in small towns and cities have been considered.

The first case (case 1) refers to a private development, for the construction of a detached house with garage in the basement, located in Bargas. It has a total built surface of $644.81 \mathrm{~m} 2$, with two stories above ground and one basement. The structure is of concrete foundations, walls and beams. Slabs are one-way with prestressed joists and jack-arch clay blocks. The façade is composed of several layers: plaster, paint, double hollow brick, thermo-acoustic insulation, air chamber, cement mortar rendering, rough drilled brick and natural stone cladding. The roof of the building is a flat roof consisting on lightened mortar for the slopes (gables), waterproofing, heat insulation, geotextile and gravel filling (Figure 1).

The second studied work (case 2 ) is a public development consisting on the rehabilitation of an urban space on a street in the historic center of Toledo. Through the refurbishment of the façades, the roofs and the street paving, an environmental intervention has been performed. The surface of the façade is $1800.00 \mathrm{~m} 2$. The buildings being refurbished are buildings from different time periods with a traditional construction scheme. The buildings consist of one, two or three floors with plaster render finishes that mimic brick. The roof has eaves with timber corbels, moldings of brick and Arabic clay roof tile (Figure 1).

The third case (case 3 ) is a public development construction for educational use, located in the municipality of El Casar de Escalona. It includes four classrooms of primary school and four early childhood education classrooms. The built up area of the building is $2741.68 \mathrm{~m} 2$. The structure of the building comprises concrete foundations, walls and beams. The pillars are made of steel. The slabs are one-way with prestressed joists and jack-arch clay blocks. The façade consists of 
several layers: painting, plaster, double hollow bricks, thermo-acoustic insulation, air chamber, cement mortar rendering and face bricks. The building roof is a flat roof consisting on lightened mortar for the slopes (gables), waterproofing, heat insulation, geotextile and gravel filling.

The three works studied have had notable differences in prevention during their construction. Thus, in case 1 , the safety and health working situation was very complicated, whereas in case 2 , the situation was fair, and in case 3 , the risk was controlled. In each one of the works, three construction phases of high work accidents were analyzed: structures (Rodríguez, López \& Martínez, 2013; Adam.Pallarés \& Calderón, 2009), façades and roofs. The working risks evaluated are the most representative of those which appear during these work stages. In the three works, we have worked on the following 10 working risks, classified according to the technique applied to those risks:

- Safety at work (4): falling to a different level, falling to the same level, trapping and projecting elements.

- Industrial hygiene (2): thermal stress and poor lighting.

- Ergonomics (2): movement and handling of loads.

- Applied psychology (2): relationships and incorrect organization.

From the different evaluation methodologies of occupational risks listed in Table 1, the four risk assessment methods that best suited building works have been applied: i.e., the INSHT, ANACT, RNUR and FINE. The evaluation methods analyzed use very similar levels or risk classification. INSHT makes a risk assessment differentiating between trivial, tolerable, moderate, important and intolerable. ANACT evaluates the risk classifying it in good, regular, bad. RNUR examines whether the risk situation is very satisfactory, satisfactory, acceptable, dangerous and very dangerous. FINE makes an assessment of the risk as acceptable, possible, remarkable, high and very high. Therefore, three works have been chosen, three construction phases of high work accidents have been considered, ten risks selected and four methodologies for risk assessment were selected, obtaining a total sample of 360 results.

Results

Results have been classified according to the risk fighting techniques (safety, hygiene, ergonomic and psychology), and to the risk level. Levels of risk have been classified as low, normal, remarkable, dangerous and extreme (as qualitative parameters). These risk levels coincide with those defined by the evaluation methods studied, but with a different name. Table 2 identifies the quantifying parameters for the qualitative value of the risks. To quantify the result, a value of 1 is given to each risk factor; and the reality of the situation is observed. To highlight the extreme risk, the quantification value has been expressed in exponential variable base $3(3 x)$, where $x$ takes values from 0 to 4 .

Table 2. Qualitative and quantitative parameters. Source: self-elaboration.

\begin{tabular}{lccccc}
\hline Risk qualitative values & Very low & Normal & Notable & Dangerous & Extreme \\
\hline $\begin{array}{l}\text { Quantitative value } \\
\text { Real situation. Figure 2 }\end{array}$ & 1 & 1 & 1 & 1 & 1 \\
$\begin{array}{l}\text { Quantitative value } \\
\text { Extreme risk is highlighted Figure 4 }\end{array}$ & 1 & 3 & 9 & 27 & 81 \\
\hline
\end{tabular}

Table 3 shows the graphic codes used to differentiate the risk levels and the four risk fighting techniques where the analyzed characteristic risks are grouped.

Table 3. Graphic codes used. Source: self-elaboration.

\begin{tabular}{|c|c|c|c|c|c|}
\hline $\begin{array}{c}\text { Risk results. } \\
\text { (Figures } 2,3,4 \text { ) }\end{array}$ & Very low & Normal & Notable & Dangerous & Extreme \\
\hline \multicolumn{6}{|l|}{ Color code } \\
\hline Line code & 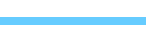 & 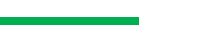 & 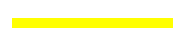 & 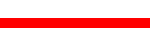 & - \\
\hline $\begin{array}{c}\text { Characteristic risks. } \\
\text { (Figure 5) }\end{array}$ & Safety & Hygiene & & mic & Psycho-sociology \\
\hline Screen code & & & & & \\
\hline
\end{tabular}

Figure 1 shows the results of the analysis carried out for each of the risks, in each one of the construction phases and for each method of evaluation, using the quantitative values of Table 2. Thus, for example, case 1 indicates notable risks of value 7 evaluated according to the method of INSHT. That means, that the risk assessment according to the method 
of INSHT, for the 10 risks listed (4 of safety at work, 2 hygiene, ergonomics 2 and 2 of psycho-sociology) in each of the three critical phases of work (structure, façade and roofs) seven moderate risk (notable) have been identified. Based on the results, a logarithmic line of the risk tendency has been generated for each of the assessment methods and in each construction.

The risk tendency in each evaluation method is identified with the line codes listed in Table 3. It can be observed that the, risk tendency matches the background described for the actual constructions. As can be seen case 1 risks have a tendency towards extreme and dangerous. Case 2 risks are balanced between normal and significant risks. Risks in case 3 show a tendency toward normal and very low risks.

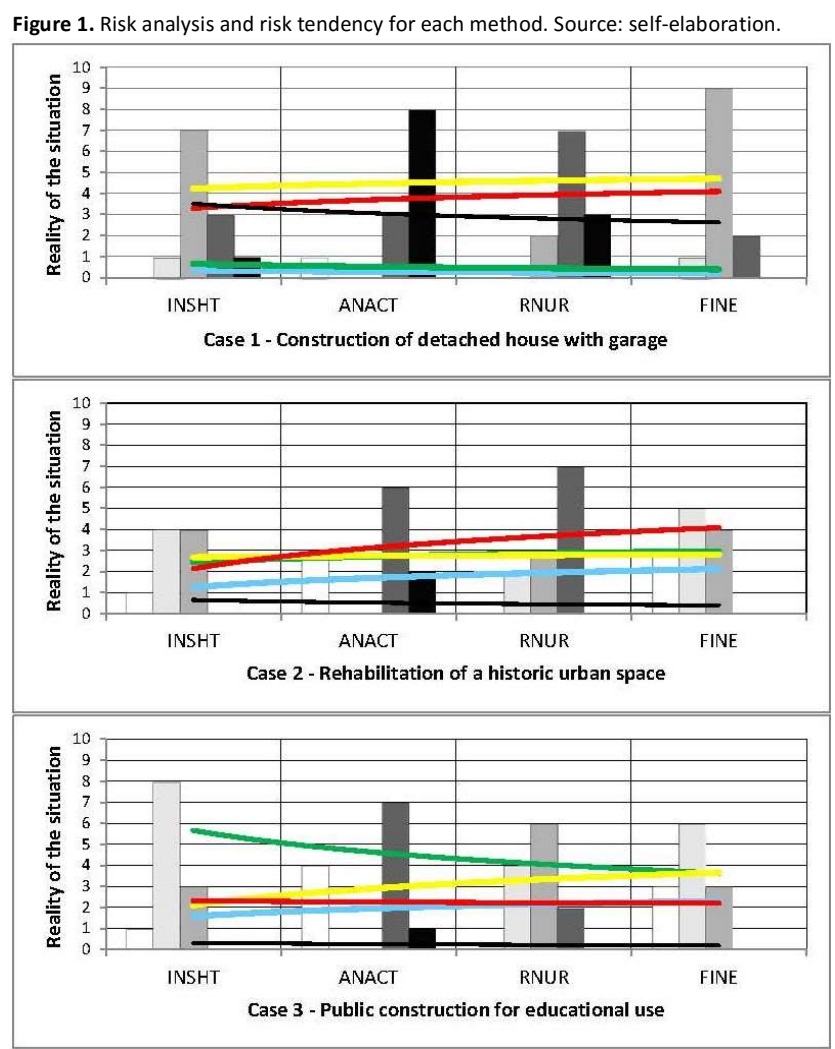

Figure 2. Percentage the risk levels identified for each method. Source: self-elaboration. 


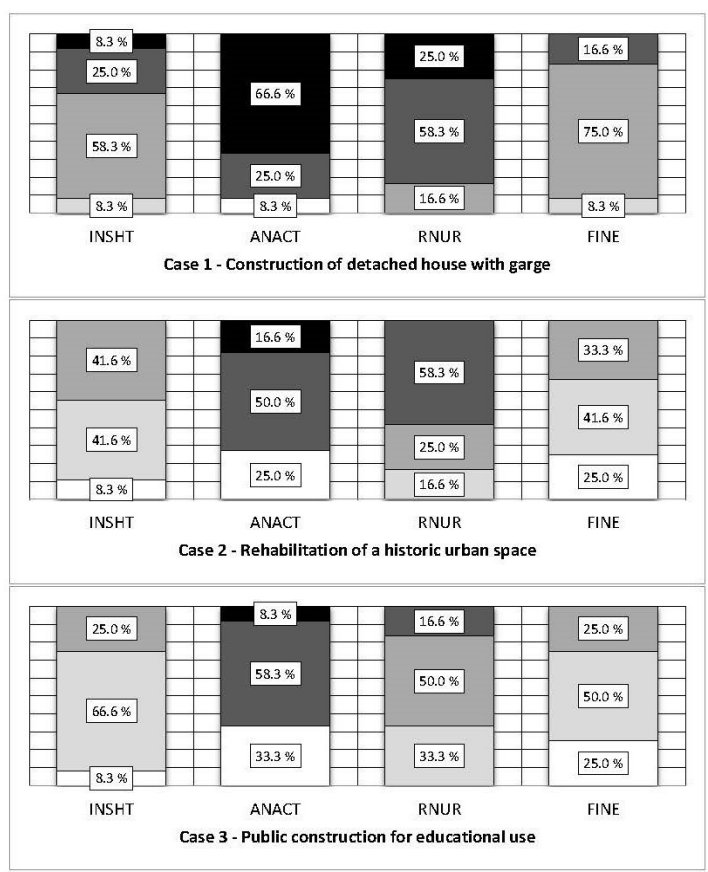

Figure 2 includes, for each risk assessment methods employed, the risk levels, which in turn, can be identified as percentage. The study was conducted on the three construction models. Overall results analysis of the three models can confirm that the results obtained on cases 2 and 3 are very similar, and at the same time, very different from those of case 1 . In addition, for each building case there is a big difference in the risk percentages, and we are able to identify each assessment method. Thus, for example, in case 1, very low risks have been identified only by the ANACT whereas, the normal risks are only identified by INSHT and FINE. In case 1, dangerous risks are identified by the four methods, and the notable and extreme ones by three methods. For case 2, the INSHT and FINE methods focus on the normal and notable risks group. While ANACT and RNUR point the band of dangerous risks. And case 3 shows a slight tendency to identify and focus on the very low, normal, and notable group risks. For case 2 and 3 , the extreme risks are only identified by ANACT method.

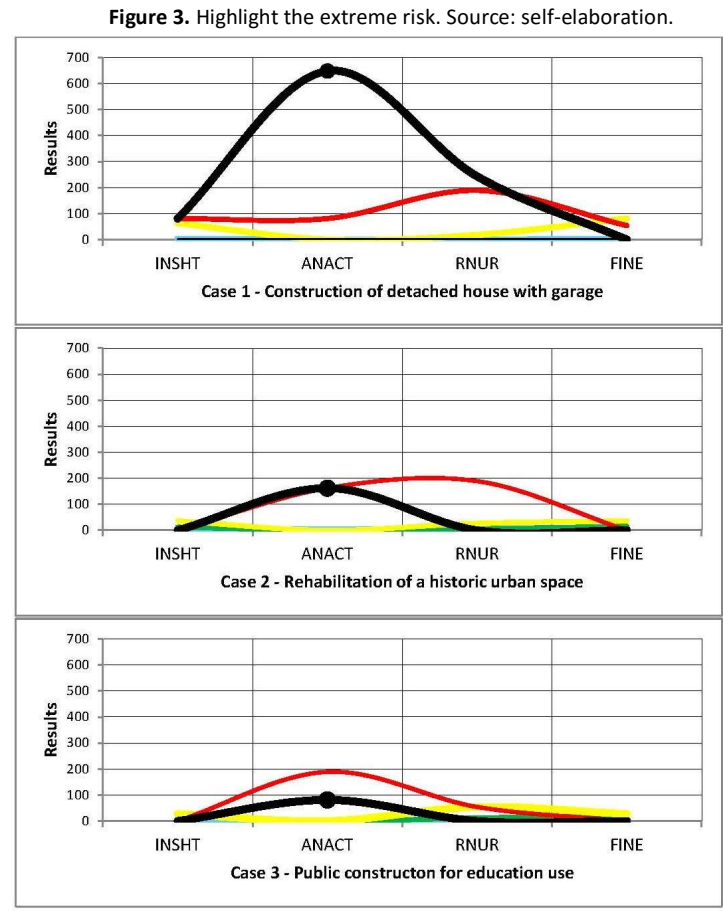




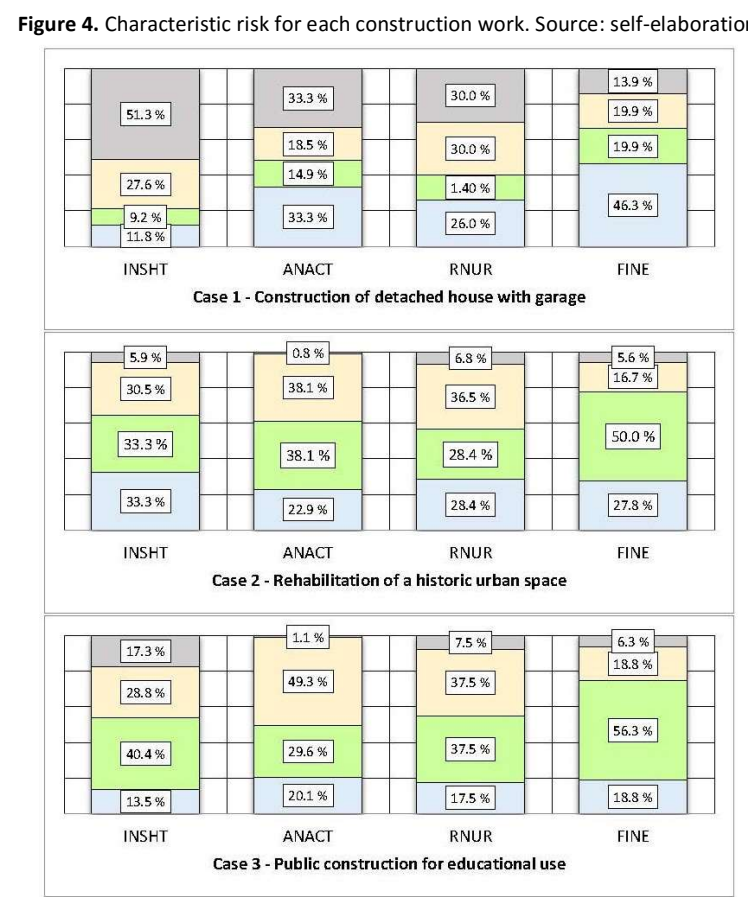

To highlight and identify dangerous risks and extreme ones from the rest of analyzed risks, a quantification value has been expressed in base three exponential variable (3x) (Figure 3). It can be observed that the four methods warn from risk danger in case 1 . In case 2 the methods suggest a risk moderation, when compared to those of case 1 . In case 3 , the INSHT, FINE and RNUR methods indicate a controlled situation of the extreme risk. These results show that the risk situation in each of the building cases is in accordance with the safety situation during the construction.

Figure 4 shows for each assessment method, the risk percentages identified by groups according to the technique studying them. From bottom up, the list is as follows: safety risks, hygiene, ergonomic and psycho-sociology (graphic code on Table 3). The overall analysis of this figure gives similar information to the one obtained from Figure 3: results obtained on cases 2 and 3 are very similar, and at the same time, different from those of case 1 . In addition, for each construction case, a big difference can be observed in risk percentages grouped by techniques that each assessment method can identify. With case 1, INSHT has more ability to detect psychosocial risks (51.3\%) than other methods of evaluation. However, on the same case, FINE has greater ability to point out safety risks (46.2\%). For cases 2 and 3 , psychosocial risks are poorly detected in the four methods, and hygiene risks are reasonably well detected by the four assessment methods. The predominant risks in case 1 are safety and psychosocial risks. In case 2 safety risks, hygiene and ergonomic ones stand out; and in case 3, risks that are especially highlighted are the hygienic and the ergonomic ones.

\section{Comparing assessment methods}

Table 4 shows a comparison of the four risk assessment methods referred to the risk selection. The risk spectrum for each of the methods has been obtained on the basis of the total results and the repetition factor. As can be seen, the INSHT and FINE methods show very similar results, covering the risk range from very low up to dangerous risks, leaving out extreme risk. RNUR method assesses from the normal risks range to the extreme danger. The ANACT method highlights the low risks and the extreme ones, leaving undefined the central area of the range. As a consequence, although the methods selected are suitable for construction works, the results obtained are very different.

Table 4. Comparison of the four risk assessment methods referred to the risk selection. Source: self-elaboration.

\begin{tabular}{l} 
Table 4. Comparison of the four risk assessment methods referred to the risk selection. Source: self-elaboration. \\
\hline Very low \\
\hline INSHT
\end{tabular}

Table 5. Comparison between safety, hygiene, ergonomics and psychosociology risks. Source: self-elaboration. 


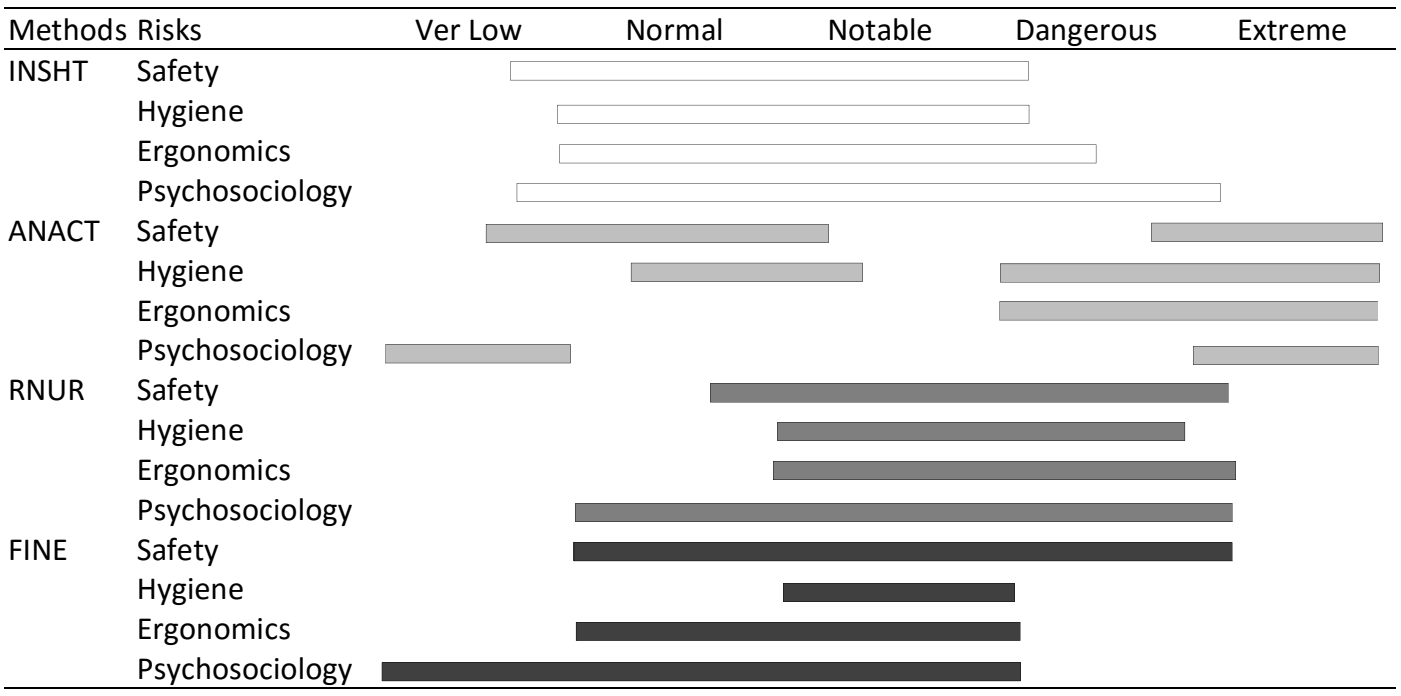

Table 5 shows the results of Table 4 breaking the risks down into the four fighting techniques offered: safety, hygiene, ergonomics and psycho-sociology. Each evaluation method identifies the risks differently.

The INSHT method appreciates safety, hygiene and ergonomics risks approximately equal, with a special difficulty tin identifying he dangerous and extreme risks. However, in the case of psychosocial risks, the latter (dangerous and extreme) ones are identified.

ANACT method is not able of detecting very low, normal or significant ergonomic risks. Neither does it identify notabledangerous safety risks, notable and normal hygiene ones, nor notable or dangerous psychosociology risks. The RNUR method does not detect very low, normal and extreme safety, hygiene and ergonomics risks and neither does it identify very low or extreme psycho-sociology ones.

The FINE method only detects notable hygiene risks. It does not identify any extreme risk, and it only detects very low psychosociology risks and dangerous safety risks. Thus, it can be concluded that if only a single evaluation method is used, the results obtained deviate from reality. For example, there are methods that are not capable of detecting very low or extreme risks in any of the risk fighting techniques.

\section{Conclusions}

Risk evaluation methods must incorporate and unify concepts of the building works, adapting to the complexity of organization and management of construction works. INSHT is a qualitative and easy to apply method. Risk tolerance levels are obtained from qualitative assessments very difficult to perform in a building work. ANACT and RNUR are qualitative and hard to perform methods. These methodologies focus on the social environment of the company with very extreme valuation levels and very difficult to interpret results in a building construction to integrate prevention.

FINE is a quantitative and complex method. Of the four methods studied in this research, it is the one that best fits the building works, since it incorporates parameters that can be adapted to the reality of the construction works. From the overall analysis of the results on the three cases, the following conclusions can be drawn: the results obtained on cases 2 and 3 are very similar, and at the same time, very different from those of the case 1 . This happens when we analyzing the percentage the risk levels that can detect each evaluation method, together with the percentage of risks classified by risk techniques capable of being identified by each assessment method.

For each construction case, a big difference in the risk percentages able to be identified by each method of assessment can be observed. When analyzing the risks according to the exponential base, results show that the risk situation for each of the construction cases is in accordance with the actual safety situation, as the one shown during its execution. Depending on the type of building work studied, each evaluation method used is able to detect different types of risks. Depending on the construction type there are assessment methods, which are not able to detect practically any risk. If only one method of evaluation is used, the results deviate from reality. There are methods that are not able of detecting very low or extreme risk in any of the risk fighting techniques. A new methodology for risk assessment in building works is necessary, and it should be able to identify all risk levels for each risk fighting technique. 
Adam, J. M., Pallarés, F. J., \& Calderón, P. A. (2009). Falls from height during the floor slab formwork of buildings: Current situation in Spain. Journal of Safety Research, 40(4), 293-299. https://doi.org/10.1016/j.jsr.2009.07.003

Ahonen, M., Launis, M., \& Kuorinka, T. (1989). Ergonomic workplace analysis. Finland: Finnish Institute of Occupational Health.

Aneziris, O. N., Topali, E., \& Papazoglou, I. A. (2012). Occupational risk of building construction. Reliability Engineering \& System Safety, 105, 36-46. https://doi.org/10.1016/j.ress.2011.11.003

Behm, M. (2005). Linking construction fatalities to the design for construction safety concept. Safety Science, 43(8), 589-611. https://doi.org/10.1016/j.ssci.2005.04.002

Bestratén, M. (1994). NTP 328: Análisis de riesgos mediante el árbol de sucesos. Spain.

Bobick, T. G. (2004). Falls through roof and floor openings and surfaces, including skylights. Journal of Construction Engineering and Management, 130(6), 895-907.

BOE. Ley 31/1995, de 8 de noviembre, de Prevención de Riesgos Laborales (1995). Spain: Boletín Oficial del Estado.

Camino López, M. Á., Ritzel, D. O., Fontaneda, I., \& González Alcantara, O. J. (2008). Construction industry accidents in Spain. Journal of Safety Research, 39(5), 497-507.

Chavarría, R. NTP-176. Evaluación de las condiciones de trabajo: Método de los perfiles de puestos (1986). Spain.

Chi, C.-F., Chang, T.-C., \& Ting, H.-I. (2005). Accident patterns and prevention measures for fatal occupational falls in the construction industry. Applied Ergonomics, 36(4), 391-400. https://doi.org/10.1016/j.apergo.2004.09.011

Conte, J. C., Rubio, E., García, A. I., \& Cano, F. (2011). Occupational accidents model based on risk-injury affinity groups. Safety Science, 49(2), 306314. https://doi.org/10.1016/j.ssci.2010.09.005

Dong, W., Vaughan, P., Sullivan, K., \& Fletcher, T. (1995). Mortality Study of Construction Workers in the UK. International Journal of Epidemiology, 24(4), 750-757. https://doi.org/10.1093/ije/24.4.750

Embrey, D. E. (1986). SHERPA: A systematic human error reduction and prediction approach. In Proceedings of the international topical meeting on advances in human factors in nuclear power systems (pp. 21-24). Knoxville, TN, USA.

European Commission. (2008). Causes and circumstances of accidents at work in the EU. Belgium.

Faber, M. H., \& Stewart, M. G. (2003). Risk assessment for civil engineering facilities: critical overview and discussion. Reliability Engineering \& System Safety, 80(2), 173-184. https://doi.org/10.1016/S0951-8320(03)00027-9

Ferdous, R., Khan, F., Sadiq, R., Amyotte, P., \& Veitch, B. (2009). Handling data uncertainties in event tree analysis. Process Safety and Environmental Protection, 87(5), 283-292. https://doi.org/10.1016/j.psep.2009.07.003

Fine, W. T. (1971). Mathematical evaluation for controlling hazards. Journal of Safety Research, 3(4), 157-166.

Fosbroke, D., \& Chen, G. X. (1998). Work-related fatal injury risk of construction workers by occupation and cause of death. Human and Ecological Risk Assessment, 4(6), 1371-1390.

Fung, I. W. H., Tam, V. W. Y., Lo, T. Y., \& Lu, L. L. H. (2010). Developing a Risk Assessment Model for construction safety. International Journal of Project Management, 28(6), 593-600. https://doi.org/10.1016/j.ijproman.2009.09.006

Gadd, S. A., Keeley, D. M., \& Balmforth, H. F. (2004). Pitfalls in risk assessment: examples from the UK. Safety Science, 42(9), 841-857. https://doi.org/10.1016/j.ssci.2004.03.003

Gambatese, J. A., Behm, M., \& Rajendran, S. (2008). Design's role in construction accident causality and prevention: Perspectives from an expert panel. Safety Science, 46(4), 675-691. https://doi.org/10.1016/j.ssci.2007.06.010

Gangolells, M., Casals, M., Forcada, N., Roca, X., \& Fuertes, A. (2010). Mitigating construction safety risks using prevention through design. Journal of Safety Research, 41(2), 107-122. https://doi.org/10.1016/j.jsr.2009.10.007

Haslam, R. A., Hide, S. A., Gibb, A. G. F., Gyi, D. E., Pavitt, T., Atkinson, S., \& Duff, A. R. (2005). Contributing factors in construction accidents. Applied Ergonomics, 36(4), 401-415. https://doi.org/10.1016/j.apergo.2004.12.002

Hatipkarasulu, Y. (2010). Project level analysis of special trade contractor fatalities using accident investigation reports. Journal of Safety Research 41(5), 451-457. https://doi.org/10.1016/j.jsr.2010.08.005

Hermanus, M. A. (2007). Occupational health and safety in mining-status, new developments, and concerns. The Journal of The Southern African Institute of Mining and Metallurgy, 107, 531-538.

Jannadi, O. A., \& Almishari, S. (2003). Risk Assessment in Construction. Journal of Construction Engineering and Management, 129(5), 492-500. https://doi.org/10.1061/(ASCE)0733-9364(2003)129:5(492)

Lewis, C. M., \& Stine, W. W. (1989). Hidden dependence in human errors. IEEE Transactions on Reliability, 38(3), 296-300. https://doi.org/10.1109/24.44170 
López-Arquillos, A., \& Rubio-Romero, J. C. (2015). Proposed Indicators of Prevention Through Design in Construction Projects. Revista de La Construcción, 14(2), 58-64. https://doi.org/10.4067/S0718-915X2015000200008

López Arquillos, A., Rubio Romero, J. C., \& Gibb, A. (2012). Analysis of construction accidents in Spain, 2003-2008. Journal of Safety Research, 43(56), 381-388. https://doi.org/10.1016/j.jsr.2012.07.005

Lorent, P. (1987). Les conditions de travail dans l'industrie de la construction, productivité, conditions de travail, qualité concertée et totale. Brussels, Belgium: CNAC.

Marhavilas, P. K., Koulouriotis, D., \& Gemeni, V. (2011). Risk analysis and assessment methodologies in the work sites: On a review, classification and comparative study of the scientific literature of the period 2000-2009. Journal of Loss Prevention in the Process Industries, 24(5), 477-523. https://doi.org/10.1016/j.jlp.2011.03.004

Martínez Aires, M. D., Rubio Gámez, M. C., \& Gibb, A. (2010). Prevention through design: The effect of European Directives on construction workplace accidents. Safety Science, 48(2), 248-258. https://doi.org/10.1016/j.ssci.2009.09.004

Ministerio de Empleo y Seguridad Social. (2016). Informe anual de accidentes de trabajo en España. Retrieved April 3, 2017, from http://www.oect.es/Observatorio/3 Siniestralidad laboral en cifras/Informes anuales de accidentes de trabajo/Ficheros/InformeAnual2015.pdf

Nogareda, C. (2000). NTP 210: Análisis de las condiciones de trabajo: método de la A.N.A.C.T.

Nogareda Cuixart, S. (1995). NTP 387: Evaluación de las condiciones de trabajo: método del análisis ergonómico del puesto de trabajo.

Pérez, F. (1986). NTP 175: Evaluación de las Condiciones de Trabajo: el método L.E.S.T.

Pérez, J., \& Nogareda, C. (2012). NTP 926: Factores psicosociales: metodología de evaluación.

Pinto, A., Nunes, I. L., \& Ribeiro, R. A. (2011). Occupational risk assessment in construction industry - Overview and reflection. Safety Science, 49(5), 616-624. https://doi.org/10.1016/j.ssci.2011.01.003

Pinto, A., Ribeiro, R. A., \& Nunes, I. L. (2012). Fuzzy approach for reducing subjectivity in estimating occupational accident severity. Accident Analysis \& Prevention, 45, 281-290. https://doi.org/10.1016/j.aap.2011.07.015

Ringen, K., Englund, A., Welch, L., Weeks, J. L., \& Seegal, J. L. (1995). No Title. Occupational Medicine - State of the Art Reviews, $10(2), 255-259$.

Rodríguez Garzón, I., Martínez-Fiestas, M., \& López Alonso, M. (2013). El riesgo percibido por el trabajador de la construcción: ¿qué rol juega el oficio? Revista de La Construcción, 12(3), 83-90. https://doi.org/10.4067/S0718-915X2013000300010

Rozenfeld, O., Sacks, R., Rosenfeld, Y., \& Baum, H. (2010). Construction Job Safety Analysis. Safety Science, 48(4), 491-498. https://doi.org/10.1016/j.ssci.2009.12.017

Rubio Romero, J. C. (2005). Manual para la formación de nivel superior en prevención de riesgos laborales. Spain: Díaz de Santos.

Segarra Cañamares, M., Villena Escribano, B. M., González García, M. N., Romero Barriuso, A., \& Rodríguez Sáiz, A. (2017). Occupational riskprevention diagnosis: A study of construction SMEs in Spain. Safety Science, 92, 104-115. https://doi.org/10.1016/j.ssci.2016.09.016

Sesé, A., Palmer, A. L., Cajal, B., Montaño, J. J., Jiménez, R., \& Llorens, N. (2002). Occupational safety and health in Spain. Journal of Safety Research, 33(4), 511-525. https://doi.org/10.1016/S0022-4375(02)00054-3

Silva, S., Araújo, A., Costa, D., \& L. Meliá, J. (2013). Safety Climates in Construction Industry: Understanding the Role of Construction Sites and Workgroups. Open Journal of Safety Science and Technology, 3(4), 80-86. https://doi.org/10.4236/ojsst.2013.34010

Suárez-Cebador, M., Rubio-Romero, J. C., \& López-Arquillos, A. (2014). Severity of electrical accidents in the construction industry in Spain. Journal of Safety Research, 48, 63-70. https://doi.org/10.1016/j.jsr.2013.12.002

Tam, C. M., Zeng, S. X., \& Deng, Z. M. (2004). Identifying elements of poor construction safety management in China. Safety Science, 42(7), 569-586. https://doi.org/10.1016/j.ssci.2003.09.001

Tixier, J., Dusserre, G., Salvi, O., \& Gaston, D. (2002). Review of 62 risk analysis methodologies of industrial plants. Journal of Loss Prevention in the Process Industries, 15(4), 291-303. https://doi.org/10.1016/S0950-4230(02)00008-6

Waehrer, G. M., Dong, X. S., Miller, T., Haile, E., \& Men, Y. (2007). Costs of occupational injuries in construction in the United States. Accident Analysis \& Prevention, 39(6), 1258-1266. https://doi.org/10.1016/j.aap.2007.03.012

Williams, T. M. (1993). Risk-management infrastructures. International Journal of Project Management, 11(1), 5-10. https://doi.org/10.1016/02637863(93)90003-6

Zhi, H. (1995). Risk management for overseas construction projects. International Journal of Project Management, $13(4)$, 231-237. https://doi.org/10.1016/0263-7863(95)00015-I 